Indonesian Journal of Theology 4/2 (December 2016): 237-256

\title{
TAFSIR ALEGORIS, KONSTRUKSI TEOLOGIS DAN UNSUR EROTIS DALAM KITAB KIDUNG AGUNG
}

\author{
Agetta Putri Wijaya
}

\begin{abstract}
Song of Songs is afforded relatively rare attention in church, where an allegorical mode of reading often continues to serve as the default interpretative strategy for examining this particular book of the Bible. And this remains the case, despite development of numerous other approaches that can better account for elements of eroticism as contained in that book. In this essay, discursive problematics arising from the interpretation of Song of Songs are considered in detail, in order to ascertain the reason for the church's aversion toward using some such exegetical method that would be more attuned to the erotic elements within Song of Songs. One's own willingness to be open to such erotic elements in Song of Songs may even assist in bringing the church to realize the riches to be found therein. Such riches may then also serve as basis for a more progressive constructive theology concerning human sexuality. As such, the church may thus regard Song of Songs as its biblical warrant for constructing a theology that regards sexuality in a more positive manner.
\end{abstract}

Keywords: Song of Songs, hermeneutics, constructive theology, sexuality, exegetical method, sexual desire

\begin{abstract}
Abstrak
Kidung Agung merupakan kitab yang relatif jarang diberi perhatian di gereja. Pendekatan alegoris masih sering dipergunakan untuk melihat teks ini kendati berbagai pendekatan yang lebih terbuka terhadap unsur-unsur erotis di dalamnya juga telah dihasilkan. Dalam karya tulis ini, persoalan-persoalan yang timbul sebagai wacana dalam penafsiran kitab Kidung Agung akan dibahas dengan terperinci demi menemukan penyebab keengganan gereja untuk memanfaatkan metode tafsir yang lebih terbuka dalam memandang unsur-unsur erotis di dalamnya. Kesediaan untuk membuka diri terhadap unsur-unsur erotis yang
\end{abstract}


terdapat dalam kitab Kidung Agung dapat membawa gereja untuk melihat kekayaan-kekayaan yang terdapat dalam kitab Kidung Agung. Kekayaan-kekayaan tersebut berpeluang menjadi dasar bagi konstruksi teologi yang lebih progresif terkait seksualitas manusia. Dengan demikian, gereja dapat menjadikan Kidung Agung sebagai dasar biblis yang menolong mereka membangun teologi yang memandang seksualitas secara positif.

Kata-Kata Kunci: Kidung Agung, penafsiran, konstruksi teologis, seksualitas, metode tafsir, hasrat seksual

\section{Pendahuluan}

Kidung Agung merupakan salah satu sumber teologi yang mendapat bagian relatif kecil dalam kehidupan bergereja. Tidak banyak Pendalaman Alkitab atau khotbah yang menggunakan Kidung Agung sebagai teks yang dibahas. Pendekatan tafsir Kidung Agung yang diterima gereja pada umumnya terbatas pada pendekatan alegoris. Dengan pendekatan tersebut, nyanyian-nyanyian dalam Kidung Agung dilihat sebagai kiasan yang mengungkapkan keintiman hubungan antara Allah dengan manusia. ${ }^{1}$ Pendekatan ini sebenarnya bukanlah satu-satunya pendekatan yang dapat digunakan untuk menafsir kitab Kidung Agung.

Penafsiran Kidung Agung dengan menggunakan pendekatan yang lebih terbuka terhadap unsur-unsur erotis di dalamnya sudah banyak dilakukan. Salah seorang teolog Indonesia yang mengembangkan pendekatan ini untuk menafsir kitab Kidung Agung adalah J. A. Telnoni. Tulisannya yang memuat tafsir Kidung Agung dengan pendekatan tersebut diberi judul Tafsiran Kidung Agung: Kidung Pembebasan, Kidung Solidaritas Perempuan, Kidung Kesetaraan Perempuan dan Laki-laki. Selain itu, Asnath Natar dalam tulisannya yang dimuat dalam jurnal Diskursus vol. 14 no. 2 juga berhasil memunculkan dimensi feminis yang terdapat dalam kitab Kidung Agung menggunakan metode yang berpusat pada unsur narasi kitab tersebut. ${ }^{2}$ Kendati sudah banyak pendekatan tafsir yang digunakan dalam menafsir Kidung Agung, pendekatan-pendekatan tersebut belum familiar bagi banyak gereja dan masih sangat jarang digunakan. Menurut saya, hal ini terjadi

\footnotetext{
${ }^{1}$ J. Paul Tanner, "The History of Interpretation of the Song of Songs," in Bibliotheca Sacra Vol. 154 January-March (Illionis: American Theological Library Association, 1997), 23-46.

2 Asnath N. Natar, "Realitas Perempuan dalam Kidung Agung Menurut Teologi Feminis," Diskursus, Vol. 14, No. 2 (2015): 249-269.
} 
bukan karena pendekatan tersebut tidak menyediakan tafsiran Kidung Agung yang cukup baik, melainkan karena gereja masih memandang seksualitas dan unsur-unsur erotis secara umum sebagai sesuatu yang rendah.

Kidung Agung dengan segala kekayaannya sebenarnya berpotensi menjadi sumber biblis yang dapat menolong kekristenan merumuskan konstruksi teologi yang progresif terkait dengan seksualitas. Namun demikian, demi menemukan kekayaan-kekayaan tersebut, diperlukan metode-metode tafsir yang lebih beragam dan terbuka terhadap unsur-unsur erotis yang terdapat di dalamnya. Dengan demikian, berbagai persoalan teologis yang disebabkan oleh keterbatasan sumber untuk meninjau isu-isu kontemporer dapat teratasi.

\section{Kidung Agung}

Kontroversi mengenai kitab Kidung Agung sebagai bagian dari Kitab Suci Ibrani telah dimulai sejak lama. Bahkan setelah proses kanonisasi selesai, keberadaan kitab Kidung Agung sebagai bagian dari Kitab Ibrani masih menjadi perdebatan di kalangan para rabi. Perdebatan ini diakhiri dengan penerimaan dan cara pandang alegoris terhadap teks-teks dalam kitab ini berperan besar memenangkan penerimaan tersebut. Rabi Aqiba dalam pandangannya tentang Kidung Agung mengungkapkan bahwa kitab tersebut merupakan yang suci di antara kidung-kidung suci karena semua kitab adalah suci. Dalam hal ini ia memandang teks-teks Kidung Agung secara alegoris. ${ }^{3}$

Seperti halnya kitab itu sendiri, dalam perkembangannya, persoalan terkait penafsiran kitab Kidung Agung pun menimbulkan banyak perdebatan. Penafsiran dengan metode-metode lain di luar alegoris memang telah banyak dikembangkan. Namun, insting dan pandangan yang dimiliki kekristenan dan agama Yahudi sejak awal mendorong keduanya untuk menghubungkan bahasa dalam nyanyiannyanyian Kidung Agung dengan kasih yang ilahi dan melampaui manusia. ${ }^{4}$

${ }^{3}$ Marvin H. Pope, The Anchor Bible - Song of Songs (New York: Doubleday \& Company, 1977), 19.

${ }^{4}$ Ibid., 17. 


\section{Metode Alegoris dalam Penafsiran Kitab Kidung Agung}

Selama berabad-abad, kitab Kidung Agung telah ditafsirkan dengan metode alegoris. Metode alegoris merupakan sebuah pendekatan dalam proses penafsiran teks yang digagas oleh Philo, seorang Yahudi yang tinggal di Alexandria pada abad pertama. Dalam pendekatan ini, setiap bagian teks dipercaya memiliki makna lain yang lebih tinggi daripada makna literernya. Pada awalnya, Philo menawarkan pendekatan ini dengan tujuan "memperdamaikan" Septuaginta (Perjanjian Lama dalam bahasa Yunani) dengan pemikiran-pemikiran Yunani. ${ }^{5}$

Dalam tradisi Kristen, oleh karena penggunaan pendekatan alegoris dalam penafsiran Kidung Agung, kitab tersebut dianggap memuat hubungan yang intim di antara Kristus dan manusia. J. Paul Tanner, dalam artikelnya tentang sejarah penafsiran Kidung Agung mengemukakan bahwa Origenes adalah Bapa Gereja yang dikenal cukup giat mengembangkan penafsiran atas Kidung Agung dengan menerapkan metode alegoris ini. ${ }^{6}$

Seperti yang ditulis oleh Tanner, metode penafsiran alegoris yang dikembangkan Origenes ini sangat dipengaruhi oleh sikap kelompok Gnostik dan pandangan Platonik terhadap seksualitas manusia. Hal senada diungkapkan juga oleh Stephen Garton dalam bukunya, History of Sexualities, khususnya ketika ia membahas bab mengenai Sexual Austerity yakni norma-norma seksual dalam tradisi kekristenan mula-mula. Pandangan yang dimaksud tidak lain adalah pandangan bahwa alam dan hal-hal fisik lain adalah jahat dan tubuh lebih rendah daripada jiwa. ${ }^{7}$ Hasrat seksual yang lebih sering dianggap sebagai bagian dari kebutuhan jasmani semata pun akhirnya dipandang secara negatif.

${ }^{5}$ Menurut Duncan S. Ferguson, Philo adalah bapak pendekatan alegoris dalam studi biblika yang ingin memperdamaikan Alkitab (PL versi Septuaginta) dengan pemikiran-pemikiran Yunani. Ia yakin bahwa cara terbaik untuk melakukan hal tersebut adalah dengan menafsir teks-teks Alkitab secara alegoris. Lih. Duncan S. Ferguson, Biblical Hermeneutics - An Introduction (Louisville: John Knox Press, 1986), 140.

6 Tanner, "The History of Interpretation of the Song of Songs," 27-28.

7 Dalam beberapa budaya, tubuh perempuan yang sedang menstruasi dianggap najis. Hipokritus dan Aristoteles bahkan beranggapan bahwa yang menyebabkan inferioritas perempuan dan perbedaan mereka dengan laki-laki adalah darah yang keluar dari tubuh mereka pada masa menstruasi. Pandangan bahwa tubuh lebih rendah dari pada jiwa pun berujung pada perendahan hubungan seksual dan anggapan bahwa hasrat seksual membawa manusia pada kejahatan. Lih. Stephen Garton, Histories of Sexuality: Antiquity to Sexual Revolution (London: Equinox, 2004), 49-51. 
Pandangan bahwa tubuh lebih rendah daripada jiwa ini turut memengaruhi sikap kekristenan terhadap seksualitas manusia secara umum, juga hasrat seksual secara khusus. Yohanes Krisostomus (347407), dalam salah satu khotbahnya pernah mengatakan, sebagaimana dikutip oleh Garton, bahwa surga yang ideal adalah surga yang bebas dari nafsu seksual dan tidak ada hasrat akan hubungan seksual di dalamnya. ${ }^{8}$ Begitu pula Agustinus (354-430), sebagaimana dikutip oleh Tannahill, secara jelas menghubungkan seks dengan kejatuhan manusia dalam dosa dalam pandangannya tentang dosa asali. ${ }^{9}$

Pemaparan di atas memperlihatkan adanya pandangan yang begitu negatif terhadap hasrat seksual manusia. Pandangan semacam ini turut mewarnai nuansa penafsiran teks-teks Alkitab, termasuk Kidung Agung. Roland K. Harrison dalam Introduction to the Old Testament menambahkan bahwa lirik-lirik yang erotis, ketiadaan tema religius yang spesifik, serta ketidakjelasan plot dalam teks-teks Kidung Agung mengarahkan para penafsir untuk menafsir Kidung Agung dengan menggunakan metode alegoris. ${ }^{10}$ Dengan demikian, terlihat bahwa konstruksi teologis yang memandang rendah seksualitas, tubuh, dan erotisisme menjadi salah satu faktor yang cukup besar memengaruhi dipertahankannya pendekatan tafsir alegoris dalam menafsir kitab Kidung Agung.

\section{Berbagai Wacana terkait Penafsiran Kidung Agung}

Kendati hingga saat ini pendekatan alegoris masih menjadi pendekatan yang cukup umum digunakan dalam menafsir kitab Kidung Agung, ada pula ahli yang beranggapan bahwa pendekatan ini cukup berbahaya bagi gereja. Dalam Tafsiran Alkitab Masa Kini vol. 2, dikatakan bahwa ketika para pembaca menganggap isi kitab ini sebagai kiasan, pembaca dapat dibawa untuk memandang secara erotis hubungannya dengan Kristus. ${ }^{11}$ Dalam hal ini terlihat bahwa sebenarnya para penafsir yang memilih pendekatan alegoris pun menyadari adanya bahaya berupa inkonsistensi dalam pandangan mereka sendiri. Ketika mereka memandang erotisme sebagai sesuatu yang "kotor" dan memilih untuk melihat erotisme dalam Kidung Agung sebagai nuansa yang mewarnai hubungan Allah dengan

\footnotetext{
8 Ibid., 48.

${ }^{9}$ Reay Tannahill, Sex in History (London: Abacus, 1980), 28.

${ }^{10}$ Roland K. Harrison, Introduction to the Old Testament (Eerdmans: Grand Rapids, 1969), 1052.

${ }_{11}$ D. Guthrie, et. al., Tafsiran Alkitab Masa Kini vol. 2 (Jakarta: Yayasan Komunikasi Bina Kasih, 1976), 351.
} 
manusia, mereka justru akan terjebak oleh pandangan tersebut. Tentu lebih sulit bagi mereka untuk menerima bahwa hubungan antara Allah dengan manusia mengandung unsur erotis karena mereka memandang erotisme sebagai sesuatu yang kotor.

Pergumulan dalam menafsir kitab Kidung Agung ini rupanya bukanlah hal yang baru. J. A. Telnoni dalam karyanya, Tafsiran Kidung Agung: Kidung Pembebasan, Kidung Solidaritas Perempuan, Kidung Kesetaraan Perempuan dan Laki-laki, mengemukakan bahwa perdebatan mengenai metode penafsiran yang digunakan dalam menafsir kitab Kidung Agung telah berkembang di kalangan umat Israel sejak sebelum gereja berdiri. Misyna dan Talmud, misalnya, banyak memperlihatkan tafsiran Kidung Agung yang menggambarkan kasih Allah bagi Israel. Kendati demikian, ada juga penafsir-penafsir yang tidak terlalu menyetujui pandangan tersebut karena menganggap hal itu sebagai pelarian dari kenyataan manusia. ${ }^{12}$

Bagi saya, apa yang dikemukakan oleh J. A. Telnoni dalam tulisannya ini menjadi bukti akan adanya realitas bahwa memang sering kali gereja masih memandang ungkapan-ungkapan lugas tentang tubuh manusia dalam kitab Kidung Agung sebagai bahasa yang dianggap kotor dan rendah. Pandangan ini membuat hasrat seksual ikut dianggap sebagai sesuatu yang rendah juga. Pada akhirnya, tawaran untuk menafsir kitab Kidung Agung dengan pendekatan realistis eksistensial menjadi sesuatu yang sulit untuk dilakukan. Dibutuhkan dekonstruksi terhadap bangunan teologi yang menganggap bahwa seksualitas manusia adalah hal yang rendah dan kotor. Dengan demikian, barulah penafsiran dengan pendekatan yang lebih lugas dapat diterima.

Alasan lain yang memunculkan persoalan dalam menafsir kitab Kidung Agung, baik di kalangan Kristen maupun Yahudi, adalah karena kitab Kidung Agung menjadi counter bagi konstruksi teologis mengenai seksualitas yang sudah dibangun. Dalam salah satu artikelnya, Asnath Niwa Natar memperlihatkan bahwa realitas tubuh dan seksualitas perempuan yang tergambar dalam Kidung Agung bertentangan dengan konstruksi tentang seksualitas yang bernuansa patriarkal yang dibangun oleh kekristenan. ${ }^{13}$ Misalnya, dalam Kidung Agung 3:1-4 dan Kidung Agung 5:2-8 peran perempuan digambarkan begitu aktif dalam mencari kekasihnya.

Pada akhirnya, kita dapat melihat bahwa persoalan dalam penafsiran kitab Kidung Agung ini terletak pada sudut pandang yang

12 J. A. Telnoni, Tafsiran Kidung Agung - Kidung Pembebasan, Kidung Solidaritas Perempuan, Kidung Kesetaraan Perempuan dan Laki-laki (Kupang: Gita Kasih, 2005), 17 21.

13 Asnath N. Natar, "Realitas Perempuan dalam Kidung Agung Menurut Teologi Feminis," 261. 
dimiliki oleh para pembaca mengenai seksualitas. Sudut pandang yang melihat seksualitas dan erotisme sebagai sesuatu yang rendah tidaklah sesuai dengan kesan yang diperlihatkan oleh Kidung Agung mengenai kedua hal tersebut. Sudut pandang ini dibentuk oleh konstruksi teologis mengenai seksualitas. Oleh karena itu, mengajak pembaca dan penafsir untuk meninggalkan metode alegoris dalam menafsir kitab Kidung Agung hanya dapat dilakukan dengan mendorong mereka untuk melepaskan sejenak konstruksi yang mereka kenakan sebagai lensa dalam memandang seksualitas manusia secara negatif. Dengan demikian, pembaca dapat mendengarkan "suara yang lebih jujur" dari kitab Kidung Agung. Hal ini tentu bukanlah hal yang mudah mengingat konstruksi tersebut sudah mapan dan dibangun sejak berabad-abad lalu.

\section{Konstruksi Teologi Kristen mengenai Seksualitas Manusia}

Konstruksi teologis yang memandang seksualitas manusia sebagai hal yang rendah telah dibangun sejak awal berdirinya kekristenan. Tulisan-tulisan para Bapa Gereja yang cukup ternama yang terekam hingga saat ini memberikan banyak bukti yang memperkuat dugaan tersebut. Tulisan-tulisan tersebut masih memiliki pengaruh yang signifikan bagi doktrin gereja masa kini. Di samping banyaknya catatan yang memuat tentang berbagai skandal seksual yang terjadi pada awal masa perkembangan gereja, kita dapat melihat bagaimana sikap gereja secara institusional dalam memandang seksualitas manusia.

Agustinus, pada masa ketika ia berkarya, menafsirkan kisah kejatuhan manusia ke dalam dosa yang ada dalam kitab Kejadian untuk menciptakan sebuah teologi yang berkitan dengan dosa asali manusia. Pandangan mengenai dosa asali ini sebenarnya sudah dituturkan sebelumnya oleh Irenaeus dan dikembangkan oleh Agustinus. Baginya, segala kejahatan yang ada di bumi saat ini diakibatkan oleh dosa manusia.

Dalam pandangan Agustinus mengenai dosa asali, semua manusia telah jatuh ke dalam dosa akibat dosa Adam dan Hawa yang diturunkan melalui cairan semen yang dikeluarkan oleh Adam ketika ia berhubungan seksual dengan Hawa. Oleh sebab itulah semua manusia telah jatuh ke dalam dosa. Yesus dalam hal ini bukanlah manusia berdosa karena kelahiran-Nya tidak melibatkan cairan semen yang dikeluarkan oleh manusia. ${ }^{14}$ Pandangan ini sangatlah berdampak pada

14 Marjorie H. Suchocki, The Fall to Violence: Original Sin in Relational Theology (New York: Continuum Publishing Company, 1999), 19-22. 
pemahaman umat mengenai hubungan seksual. Oleh karena cairan semen disebut sebagai media yang menurunkan dosa seseorang kepada keturunannya, hubungan seksual pun menjadi sarana penurunannya. Akibatnya, hubungan seksual menjadi sarat dengan dosa dan hasrat seksual menjadi sesuatu yang seharusnya sedapat mungkin diredam.

Tafsiran yang ia hasilkan tersebut sangat dipengaruhi oleh pengalaman hidupnya, khususnya kehidupan seksualnya. Sebelum ditahbiskan menjadi uskup dan memilih kehidupan selibat, Agustinus mengambil beberapa gundik dan memiliki anak dari mereka. Salah seorang anaknya yang ia ceritakan dalam karyanya De Magistro bernama Adeodatus. ${ }^{15}$ Adeodatus lahir dari gundik yang ia ambil ketika ia masih menetap di Hipo dan belum menikah. Setelah ia pindah ke Milan, ia juga memiliki seorang istri dan seorang gundik sebelum dibaptis oleh Ambrosius. Inisiasinya ke dalam kekristenan sebenarnya tidak menuntut dirinya untuk meninggalkan kehidupan seksual dan pernikahan yang sedang ia jalani. Hanya saja, ia menemukan sesuatu yang lebih tinggi yakni kehidupan asketis para filsuf Kristen. ${ }^{16}$ Proses untuk menghidupi apa yang ia anggap luhur ini juga bukanlah proses yang mudah karena pada kenyataannya, Agustinus sendiri berjuang untuk mengatasi perbenturan antara kepercayaan akan pentingnya mentransendensi hasrat jasmani dan kebutuhan akan hubungan seksual untuk mempertahankan jumlah jemaat Kristen. ${ }^{17}$

Agustinus bukanlah satu-satunya teolog yang berpandangan bahwa kisah Adam dan Hawa ada hubungannya dengan dosa oleh karena hubungan seksual. Tatianus berpandangan bahwa Adam dan Hawa diusir dari taman Eden karena melakukan hubungan seksual. Clement juga memiliki pandangan yang senada dengan Tatianus. Hanya saja, baginya, mereka berdosa bukan karena hubungan seksual itu sendiri, melainkan karena mereka melakukannya terlalu dini. ${ }^{18}$ Gregorius dari Nyssa bahkan berpendapat bahwa apabila Adam dan Hawa tidak berdosa, mereka akan tetap menjadi perawan dan manusia akan berkembang biak dengan cara yang sama dengan malaikat, bukan dengan binatang. ${ }^{19}$ Ketiganya mengaitkan hubungan seksual dengan dosa. Pandangan-pandangan ini seringnya menjadi dasar yang dipilih untuk membangun konstruksi teologi gereja mengenai seksualitas.

\footnotetext{
15 Eleonore Stump and Norman Kretzmann, The Cambridge Companion to Augustine - Classical Philosophy (Oxford: Cambridge University Press, 2006), 1.

16 Ibid., 18.

${ }^{17}$ Garton, Histories of Sexuality, 48-49.

18 Gerard Loughlin, Alien Sex - The Body and Desire in Cinema and Theology (Oxford: Blackwell Publishing, 2004), xv.

${ }^{19}$ Roger Scruton, Sexual Desire: A Philosophical Investigation (New York: Continuum Publishing Company, 1986), 106.
} 
Hieronimus juga menjadi Bapa Gereja yang turut mengonstruksi teologi Kristen mengenai seksualitas pada masanya. Dalam menentukan sikap yang harus diambil oleh gereja terhadap isuisu seksual pada masanya, pandangan Hieronimus sangatlah dipengaruhi kebijakan pemerintah Romawi ${ }^{20}$. Hal ini memperlihatkan bahwa bagaimana pun, konteks masyarakat di mana gereja berada pada masa tertentu sangatlah memengaruhi teologi mereka dalam memandang fenomena terkait seksualitas.

Menurut Tannahill, Hieronimus dan Agustinus menjadi tokoh yang dipercaya telah membuat dunia modern memahami dosa bukan berdasarkan ajaran Yesus, atau Hukum Taurat, melainkan berdasarkan pemikiran-pemikiran para imperialis Roma tentang seksualitas. ${ }^{21} \mathrm{Hal}$ senada diungkapkan juga oleh Garton, yakni bahwa teologi yang dibangun gereja mula-mula terkait dengan seksualitas manusia mendapat pengaruh juga dari budaya di sekitarnya saat itu. ${ }^{22}$

Persoalan yang terjadi dalam penafsiran Kidung Agung lagi-lagi memperlihatkan bagaimana konstruksi teologi yang dibangun memengaruhi penafsiran, khususnya metode yang dipilih dan tafsiran yang dihasilkan. Penafsiran Kidung Agung yang menjauhi unsur-unsur erotis di dalamnya ini terus berkembang hingga para penafsir mengamati bahwa dalam melihat Kidung Agung beserta dengan tafsirannya, tafsiran yang paling baik untuk menggambarkan isi dari kitab Kidung Agung adalah tafsiran yang menghadirkan citra erotis dalam kitab tersebut. Marvin Pope yang memiliki pandangan serupa mengungkapkan bahwa seksualitas adalah kepentingan dasar setiap manusia dan afirmasi bahwa "Allah adalah Cinta" mencakupi seluruh makna dari kedua kata tersebut. ${ }^{23}$

\section{Literary Form Criticism}

Dengan kesediaan membuka diri untuk melihat unsur-unsur erotis yang terdapat dalam kitab Kidung Agung, ada banyak pesan berharga yang dapat ditemukan dari penafsiran Kidung Agung. Pendekatan literer yang berpusat pada bentuk teks dalam hal ini menjadi pendekatan yang cukup proprsional untuk menafsir kitab Kidung Agung oleh karena adanya unsur sastra dan naratif yang cukup kuat dalam kitab tersebut. Selain itu, ketiadaan informasi historis dalam

\footnotetext{
${ }^{20}$ Lih. Reay Tannahill, Sex in History, 139.

${ }^{21}$ Ibid., 138.

22 Garton, Histories of Sexuality, 51.

23 Pope, The Anchor Bible - Song of Songs, 17-18.
} 
kitab Kidung Agung tidak menjadi persoalan yang berarti apabila kitab tersebut ditafsir dengan pendekatan ini.

Literary form criticsm merupakan pendekatan tafsir yang berpusat pada bentuk teks dan cara pengungkapan ide atau gagasan pada teks tertentu. Richard G. Moulton dalam bukunya The Literary Study of the Bible menglasifikasikan bentuk-bentuk karya sastra menjadi empat berdasarkan cara pengungkapan gagasan dan bentuk teksnya. ${ }^{24}$ Terdapat setidaknya dua cara mengungkapkan gagasan dan dua bentuk tulisan yang merupakan antitesis. Cara mengungkapkan gagasan yang dimaksud adalah deskripsi dan presentasi, sementara dua bentuk tulisan dalam hal ini adalah puisi/sajak dan prosa. Dalam hal ini, Moulton memasukkan Kidung Agung dalam kelompok "drama" yakni karya sastra yang gagasannya disampaikan dengan presentasi dan berbentuk puisi/sajak. Lebih spesifik lagi, ia memasukkannya ke dalam kelompok sajak yang dinyanyikan sebagai oratorio (idy $).{ }^{25}$ Dalam sebuah drama, apapun alur yang dipilih, sebuah adegan cenderung hanya dipresentasikan satu kali, sementara dalam sebuah oratorio, lebih banyak ruang untuk pengulangan, penekanan terhadap refleksi tertentu, dan alur yang lebih bebas.

Sebuah idyl atau nyanyian dapat dinyanyikan oleh siapa saja. Kendati pembagian peran dalam menyanyikan bait-bait nyanyian terlihat dengan jelas, namun tidak seperti drama, identitas orang-orang yang menyanyikannya tidak perlu diungkapkan. Dalam kitab Kidung Agung, identitas para kekasih yang menyanyikan bait-bait Kidung Agung tidak teridentifikasi dengan jelas. Latar tempat dan waktu dari puisi-puisi dalam Kidung Agung juga tidak disebutkan secara spesifik. Hal ini, menurut Cheryl Exum, menunjukkan bahwa nyanyian dalam Kidung Agung tidak dimaksudkan agar dinyanyikan pasangan tertentu melainkan menggambarkan salah satu pola hubungan pasangan kekasih secara umum. Baginya, nyanyian-nyanyian dalam Kidung Agung dapat dinyanyikan oleh seluruh pasangan dari berbagai belahan dunia dan bertahan sepanjang masa. ${ }^{26}$

Kendati tidak ada deskripsi naratif bagi sajak-sajak Kidung Agung, kalimat langsung yang digunakan untuk menjelaskan tindakantindakan yang tercatat dalam sajak-sajak Kidung Agung menunjukkan bahwa semua tindakan dilakukan pada saat yang sama. Rasa cinta dan hasrat yang dimiliki oleh kekasih yang menyanyikan sajak-sajak Kidung Agung ini terlihat melalui ucapan-ucapan mereka yang saling

\footnotetext{
${ }^{24}$ Richard G. Moulton, The Literary Study of the Bible (Boston: Norwood Press, 1986), 105-106.

25 Ibid., 194-195.

${ }^{26} \mathrm{~J}$. Cheryl Exum, Song of Songs: A Commentary (Louisville: John Knox Press, 2005), 8.
} 
bersahutan. Dalam hal ini, penulis sajak-sajak Kidung Agung memperlihatkan visi cinta yang dimiliki oleh sepasang kekasih dengan kata-kata yang konkret, yakni dengan menyebutkan apa yang dilakukan oleh pasangan kekasih tersebut terhadap satu sama lain. ${ }^{27}$

Keunikan sajak-sajak dalam Kidung Agung terletak juga pada sudut pandang yang digunakan oleh penyair. Pada umumnya, puisipuisi cinta dari daerah Timur Tengah pada masa itu hanya ditulis dalam satu sudut pandang sebagai solilog atau monolog di mana sang penyair berbicara kepada atau mengenai pihak yang menjadi sasaran dari hasratnya ${ }^{28}$. Sajak-sajak dalam Kidung Agung merupakan dialog antara seorang laki-laki, seorang perempuan, serta pihak ketiga yang disebutkan sebagai puteri-puteri Yerusalem.

\section{Kidung Agung 7:2-8:2}

Pusarmu seperti cawan yang bulat, yang tak kekurangan anggur campur Perutmu timbunan gandum, berpagar bunga-bunga bakung Seperti dua anak rusa buah dadamu, seperti anak kembar kijang Lehermu bagaikan menara gading, Matamu bagaikan telaga di Hesybon, dekat pintu gerbang Batrabim;

Hidungmu seperti menara di gunung Libanon, yang menghadap ke kota Damsyik Kepalamu seperti bukit Karmel, rambut kepalamu merah lembayung;

Seorang raja tertawan dalam kepang-kepangnya

Betapa cantik, betapa jelita engkau,

Hai tercinta di antara segala yang disenangi

Sosok tubuhmu seumpama pohon koma,

Dan buah dadamu gugusannya

Kataku:"Aku ingin memanjat pohon korma itu

Dan memegang gugusan-gugusannya

Kiranya buah dadamu seperti gugusan anggur

Dan nafas hidungmu seperti buah apel

Kata-katamu manis bagaikan anggur!"

Ya, anggur itu mengalir kepada kekasihku

Dengan tak putus-putusnya,

${ }^{27}$ Ibid., 3.

${ }^{28}$ Ibid., 4. 
Melimpah ke bibir orang-orang yang sedang tidur!

(Refrain)

Kepunyaan kekasihku aku, Kepadaku gairahnya tertuju

Mari, kekasihku, kita pergi ke padang,

Bermalam di antara bunga-bunga pacar!

Mari, kita pergi pagi-pagi ke kebun anggur

Dan melihat apakah pohon anggur sudah berkuncup, Apakah sudah mekar bunganya, Apakah pohon-pohon delima sudah berbunga!

Di sanalah aku akan memberikan cintaku kepadamu!

Semerbak bau buah dudaim;

Dekat pintu kita ada pelbagai buah-buah yang lezat, Yang telah lama dan yang baru saja dipetik Itu telah kusimpan bagimu, kekasihku!

O, seandainya engkau saudaraku laki-laki, Yang menyusu pada buah dada ibuku, Akan kucium engkau bila kujumpai di luar, Karena tak ada orang yang akan menghina aku!

Akan kubimbing engkau dan kubawa ke rumah ibuku, Supaya engkau mengajar aku

Akan kuberi kepadamu anggur yang harum untuk diminum, Air buah delimaku ${ }^{29}$

Seperti nyanyian pada umumnya, penulis Kidung Agung 7:28:2 tidak mencantumkan identitas pasangan kekasih yang menjadi tokoh dalam nyanyian tersebut. Hal ini membuat pembaca tidak dapat mengidentifikasi secara pasti siapakah pasangan kekasih yang menyanyikan nyanyian itu, apa status mereka, dari mana mereka berasal, atau bagaimana kehidupan mereka. Tidak ada yang tahu apakah mereka pasangan suami istri atau bukan, atau hubungan macam apa yang sebenarnya terjadi di antara mereka. Mungkin saja mereka bukan suami-istri, atau bahkan sudah bersuamikan atau beristrikan orang lain. Tidak ada yang dapat memastikan hal itu. Namun demikian, ketidakjelasan identitas ini justru semakin memperlihatkan esensi dari hasrat itu sendiri. Dengan ketiadaan identitas tersebut, dengan cara

${ }^{29}$ Moulton, The Literary Study of the Bible, 214. 
yang sangat jujur pembaca disadarkan bahwa setiap orang dapat berhasrat kepada siapa saja dengan cara yang sangat indah.

Kidung Agung 7:2-8:2 menjadi bagian dari puisi cinta kedua dalam kitab Kidung Agung. ${ }^{30}$ Ayat 2-6 dalam pasal 7 merupakan bait pertama puisi tersebut. Pada bagian yang pertama ini, unsur deskriptif memang lebih dominan karena sang penyanyi memuja keindahan tubuh kekasihnya dari bagian bawah ke atas dengan kata-kata pengibaratan. Kata sarr yang diterjemahkan menjadi "pusar" pada ayat 2, menurut Lloyd Carr dalam tafsirannya terhadap Kidung Agung, lebih tepat diterjemahkan dengan "vulva" (bagian luar vagina) sebab bagian perut baru dibicarakan pada baris di bawahnya. ${ }^{31}$ Hal yang sama juga dikemukakan oleh Marvin Pope dalam tafsirannya yang dimuat The Anchor Bible. ${ }^{32}$ Penafsir lain yang juga sepakat dengan hal ini adalah Roland Murphy. Ungkapan "anggur campur" pada baris di bawah kata "pusar" pun olehnya ditafsirkan sebagai cairan vagina yang keluar dari seorang perempuan ketika hasrat seksualnya muncul. ${ }^{33}$ Pada saat itu ada kemungkinan kekasihnya itu tidak lagi mengenakan pakaian karena pakaian perempuan Yahudi pada masa itu menutup bagian-bagian yang disebutkan oleh sang penyanyi. ${ }^{34}$

Pada bait berikutnya, sang penyanyi kembali memusatkan perhatiannya pada buah dada kekasihnya. Ia tidak lagi hanya memujimuji keindahan buah dada kekasihnya, melainkan juga mengutarakan hasratnya terhadap buah dada kekasihnya itu (Kid. 7:8). Pada bagian inilah unsur dramatikal yang seolah dipresentasikan mulai muncul. Tubuh sang kekasih oleh penyanyi bait ini digambarkan seperti pohon palem. Pada masa itu, pohon palem merupakan sebuah pohon yang setiap bagiannya dapat digunakan untuk memenuhi kebutuhan manusia; minyaknya harum dan buahnya manis. Menurut Duane Garrett, bagi sang penyanyi kekasihnya itu merupakan sumber ekspresinya akan kekuatan seksual dan kesenangan yang direpresentasikan daun palem. ${ }^{35}$

Hasrat sang penyanyi terhadap tubuh kekasihnya pada bagian ini digambarkan dengan keinginan untuk memanjat pohon kurma yang gugusan-gugusannya adalah buah dada kekasihnya itu. Buah pohon kurma sangatlah manis dan buah itulah yang menarik orang-orang

30 Duane Garrett, Word Biblical Commentary - Song of Songs, Lamentation

(Texas: Word Books, 2004), 235.

31 Lloyd G. Carr, The Song of Solomon - An Introduction \& Commentary

(Illionis: Inter-Varsity Press, 1984), 157.

32 Pope, The Anchor Bible - Song of Songs, 617.

33 Roland E. Murphy, The Song of Songs (Hermeneia: A Critical \& Historical Commentary on the Bible) (Philadelphia: Fortress Press, 1990), 182.

${ }^{34}$ Garrett, Word Biblical Commentary - Song of Songs, Lamentation, 139.

35 Ibid., 244. 
untuk mencari pohon tersebut dan mengambil buahnya. Demikianlah buah dada kekasih sang penyanyi sangat kuat menariknya dan memberi kesenangan padanya. Fokus pada buah dada ini sebenarnya merupakan salah satu ciri khas bentuk syair tertentu dalam tradisi sastra Alkitab. Bagi Garrett, hal ini sesuai dengan nasihat pada Amsal 5:19, "Biarlah buah dadanya senantiasa memuaskan engkau,". ${ }^{36} \mathrm{Hal}$ ini juga menyiratkan pemahaman umum yang berkembang pada masa itu bahwa buah dada perempuan dianggap sebagai sumber yang memuaskan hasrat, dalam hal ini hasrat seksual pasangannya.

Bait selanjutnya dalam puisi ini, yakni ayat 8b-9, merupakan bagian transisi antifonal sebelum menuju ke bagian penyanyi sopran yang dinyanyikan sang perempuan. ${ }^{37}$ Dalam uraian Moulton, terlihat bahwa transisi antifonal ini berlaku sebagai refrain yang menghubungkan bait pertama dengan bait berikutnya. ${ }^{38}$

Ayat 10-13 membentuk satu bait yang dinyanyikan oleh penyanyi perempuan sebagai tanggapan dari nyanyian kekasihnya. Pada ayat 10 , ia mengatakan bahwa ia adalah milik kekasihnya dengan pengakuan bahwa gairah kekasihnya tertuju padanya. Hal ini merupakan implikasi dari tradisi setempat yang berkembang bahwa tubuh perempuan umumnya menjadi fokus dari hasrat seksual. ${ }^{39}$ Sang perempuan pun merencanakan untuk meneruskan percintaan mereka. Dalam hal ini, terlihat bahwa sang penyanyi perempuan juga menjadi pemeran yang memresentasikan adegan tertentu dalam sebuah aksi. Pada bagian inilah kitab Kidung Agung kembali memperlihatkan keunikannya dalam hal kesetaraan jender seperti yang dikemukakan oleh Natar. ${ }^{40}$ Lebih jauh lagi, dalam Kidung Agung 7:2-8:2, kesetaraan di antara laki-laki dengan perempuan ditemukan dalam hubungan seksual (sexual intercourse). ${ }^{41}$

Pada pasal 8 ayat 1 dan 2, sang kekasih perempuan mengutarakan hasratnya dengan sebuah pengandaian. Ia mengungkapkan bahwa seandainya saja mereka berdua adalah saudara, ia dapat dengan leluasa menunjukkan perasaan cintanya kepada kekasihnya. Menurut Garrett, pada masa itu, menunjukkan perasaan dengan melakukan kontak fisik dengan orang yang dikasihi bukanlah sesuatu yang lazim dalam kehidupan masyarakat Timur Dekat Kuno.

\footnotetext{
36 Ibid.

${ }^{37}$ Ibid., 245.

38 Moulton, The Literary Study of the Bible, 214.

${ }^{39}$ Garrett, Word Biblical Commentary - Song of Songs, Lamentation, 245.

${ }^{40}$ Asnath N. Natar, "Realitas Perempuan dalam Kidung Agung Menurut Teologi Feminis," 261.

${ }^{41}$ Hubungan seksual atau sexual intercourse dalam hal ini tidak selamanya dapat diterjemahkan langsung sebagai penetrasi. Proses-proses yang mendahuluinya yang melibatkan hasrat seksual juga dapat diartikan sebagai "hubungan seksual".
} 
Namun demikian, dua orang dengan ikatan darah seperti kakak-adik dapat saling mencium di depan umum. ${ }^{42}$ Situasi inilah yang diperkirakan oleh Garrett sebagai pendorong ungkapan pada pasal 8 ayat 1: "O, seandainya engkau saudaraku laki-laki, yang menyusu pada buah dada ibuku, akan kucium engkau bila kujumpai di luar, karena tak ada orang yang akan menghina aku!" Dengan demikian, semakin jelas dugaan bahwa pasangan kekasih yang dibayangkan sebagai penyanyi dalam Kidung Agung 7:2-8:2 bukanlah pasangan suami istri. Bagian ini juga dinyanyikan oleh penyanyi perempuan dan kesan bahwa dalam hubungan seksual yang terjadi di antara mereka merupakan inisiatif keduanya menjadi semakin terlihat. Dalam salah satu sajak cinta dari Mesir, istilah "buah delima" merupakan penggambaran payudara perempuan dan dalam hal ini istilah "buah delima" di bagian akhir nyanyian diperkirakan memiliki makna yang sama dengan konotasi yang lebih erotis. ${ }^{43}$

Dengan melihat bentuk dan cara pengungkapan gagasan dalam teks Kidung Agung 7:2-8:2, pembaca dibawa untuk membayangkan dengan lebih jelas situasi yang terjadi ketika nyanyian ini dinyanyikan. Hasrat yang ada dalam diri pasangan kekasih penyanyi nyanyian ini terhadap satu sama lain tergambar dari pengandaian-pengandaian dan aksi atau tindakan yang tertuang dalam syair nyanyian tersebut. Dalam nyanyian ini, sepasang kekasih saling memuji-muji dan menyatakan hasrat mereka terhadap yang lain. Dengan sangat jujur sang kekasih pria mengagumi keindahan tubuh kekasihnya dan menyatakan hasratnya terhadap tubuh tersebut (ay. 6-8). Sementara itu, sang kekasih perempuan menyatakan hasratnya untuk memberikan cintanya pada kekasihnya (ay. 12). Hasrat yang terlihat dalam dialog pasangan kekasih tersebut memperlihatkan eksistensi keduanya sebagai manusia yang hidup dan nyata. Oleh karena itu, sangatlah relevan apa bila bagian teks ini menjadi dasar untuk melihat manusia dan hasrat seksual sebagai bagian dari mereka.

Secara eksplisit, Kidung Agung 7:2-8:2 memang tidak menyebutkan istilah hasrat seksual. Kendati demikian, kata-kata yang terangkai dalam nyanyian tersebut menggambarkan bagaimana sepasang kekasih saling mengutarakan hasratnya terhadap yang lain. Dalam hal ini, penulis teks Kidung Agung tidak menunjukkan kesan negatif sedikit pun terhadap hasrat seksual yang terlihat dari dialog pasangan kekasih dalam Kidung Agung 7:2-8:2. Penulis justru menggambarkan hasrat dan usaha untuk memenuhi hasrat tersebut dalam suatu dinamika yang indah dan membuai pembaca.

\footnotetext{
${ }^{42}$ Garrett, Word Biblical Commentary - Song of Songs, Lamentation, 247.

${ }^{43}$ Carr, The Song of Solomon - An Introduction \& Commentary, 167.
} 


\section{Refleksi atas Tafsir Kidung Agung 7:2-8:2}

Ketika seksualitas kerap kali dihubungkan dengan kekuasaan, kekerasan, bahkan penindasan, Kidung Agung 7:2-8:2 justru memunculkan wajah yang lain dari seksualitas, yang bertolak dari pendorong terjadinya kontak seksual itu sendiri, yakni hasrat. Christopher Ryan dan Cacilda Jetha dalam buku mereka Sex at Dawn mengemukakan bahwa manusia pada dasarnya merupakan keturunan dari leluhur dengan dorongan atau hasrat seksual yang tinggi. ${ }^{44}$ Otak manusia yang begitu kompleks membentuk mereka secara natural menjadi makhluk hiperseksual. ${ }^{45}$ Dengan demikian, ungkapanungkapan hasrat yang tergambar dalam Kidung Agung 7:2-8:2 baik yang dinyanyikan oleh kekasih laki-laki maupun perempuan, merupakan ungkapan yang natural dan jujur. Pengakuan kekasih lakilaki tentang cairan vagina kekasihnya yang tidak berhenti keluar yang diibaratkan seperti "anggur campur" memperlihatkan hasrat kekasihnya itu yang meluap ketika mereka bertemu. Juga keinginannya untuk "memanjat pohon korma" dan "menggaapai gugusangugusannya" menjadi penanda keduanya saling mengingini satu sama lain.

Melalui nyanyian yang sangat intim dan jujur yang tertulis dalam Kidung Agung 7:2-8:2, sebenarnya setiap orang seperti diperhadapkan pada cermin yang memproyeksikan momen-momen pemenuhan hasratnya bersama orang yang kepadanya hasrat tersebut tertuju. Dengan demikian, dapat dikatakan bahwa teks ini memuat kesaksian yang lebih jujur mengenai hasrat seksual manusia dibandingkan dengan teks-teks lain yang berbicara mengenai seksualitas, misalnya kisah Hosea dan Gomer, Daud dan Batsyeba, Yehuda dan Tamar, dan lain sebagainya.

Ketika gereja tetap bertahan dengan konstruksi yang merendahkan tubuh dan hasrat seksual, gereja akan terus terjebak pada inkonsistensi yang disebabkan oleh penafsiran yang tidak lain adalah hasil dari konstruksi tersebut. Tidak hanya itu, gereja akan sulit menemukan dasar biblis yang relevan terkait dengan realita saat ini. Jika direnungkan, telah berabad-abad gereja membuat peraturan terkait kehidupan seksual umat, bahkan tidak segan-segan memberikan sanksi pada pelanggarnya. Namun, hal tersebut tidak juga membuat persoalan-persoalan terkait seksualitas hilang. Perselingkuhan, pemerkosaan, dan praktik prostitusi tidak pernah berhenti terjadi. 2010), 2

${ }^{44}$ Christopher Ryan and Cacilda Jetha, Sex at Dawn (New York: Harper,

45 Ibid., 84. 
Di dalam Kidung Agung 7:2-8:2 hasrat seksual yang dimiliki sepasang kekasih terhadap satu sama lain tidaklah dilihat sebagai suatu dosa atau kekejian. Erotisme yang dihadirkan oleh hasrat tersebut justru dipandang sebagai sebuah keindahan. Melalui nyanyian ini, sebenarnya pembaca pun sudah dapat melihat bahwa hasrat adalah suatu kekuatan yang membawa keindahan. Hasrat seksual khususnya, menjadi indah karena hasrat tersebut bergerak menuju kenikmatan seksual dalam diri orang lain sebagai pemenuhannya. Hal ini bukanlah sesuatu yang menentang kehendak Allah, melainkan mengakui sisi kemanusiaan manusia. Lebih jauh lagi, pengakuan akan keindahan erotisme yang didorong oleh hasrat seksual tadi juga menjadi penyataan syukur atas pemeliharaan Allah yang memenuhi kebutuhan manusia akan keberadaan orang lain.

Dengan memandang nyanyian dalam Kidung Agung 7:2-8:2 sebagai nyanyian hasrat, pembaca dapat menemukan bahwa kekristenan sebenarnya memiliki sumber berteologi yang secara jujur dan otentik berbicara mengenai hasrat seksual manusia. Apabila pembaca bersedia menggunakan metode tafsir yang lebih terbuka terhadap kitab ini, dalam hal ini Literary Form Criticism, teks dalam Kidung Agung dapat dianalisa sesuai bentuk dan gagasannya sehingga jiwa dari karya sastra tersebut semakin terlihat. Sumber biblis ini berpeluang menjadi dasar bagi konstruksi teologis yang lebih umum berbicara mengenai seksualitas. Dengan teks ini, gereja mendapatkan lensa baru untuk memandang fenomena seksual yang terjadi dalam kehidupan manusia. Gereja pun dituntun untuk lebih membuka diri dalam mendengarkan nyanyian hasrat yang dilantunkan oleh setiap orang di dalam diri mereka.

Nyanyian dalam Kidung Agung 7:2-8:2 memperlihatkan bahwa hasrat seksual menyingkapkan kebutuhan manusia akan keintiman dengan orang lain. Penghayatan akan hal tersebut membawa kita pada pengertian bahwa kebutuhan seksual merupakan kebutuhan manusia yang dipenuhi oleh Allah dengan cara menghadirkan orang lain, siapa pun, dari kalangan mana pun, dalam kehidupan mereka. Dengan kesadaran ini, setiap orang dapat melihat sesamanya - siapa pun mereka, baik perempuan maupun laki-laki, baik orang kaya maupun miskin, baik berpendidikan rendah maupun berpendidikan tinggi, kaum fundamentalis, para humanis, kaum difabel, siapa pun tanpa terkecuali-sebagai individu yang memiliki keindahan dan kapasitas untuk memenuhi kebutuhan akan keintiman. Setiap orang berpeluang untuk menjadi orang yang dihadirkan sebagai pemenuh kebutuhan seksual orang lain. Dengan demikian, pemaknaan dan penghargaan akan kehadiran orang lain sebagai sesama kita menjadi lebih mendalam. Sebagaimana kita dapat menjadi anugerah yang memuaskan hasrat 
orang lain, orang lain pun dapat menjadi anugerah yang dapat memuaskan hasrat dalam diri kita. Dengan pandangan yang demikian, kasus-kasus seperti pemerkosaan dan eksploitasi seksual lainnya seharusnya tidak terjadi.

Nyanyian hasrat dalam kitab Kidung Agung ini juga memperlihatkan bahwa karya Allah yang dinyatakan dalam hasrat seksual manusia tidak hanya terlihat pada saat pemenuhannya. Upayaupaya yang terjadi dalam proses pemenuhan hasrat seksual itu sendiri merupakan wujud anugerah yang turut menghadirkan kenikmatan yang terjadi oleh karena keintiman dua orang yang saling berhasrat. Syair Kidung Agung ini tidak memperlihatkan peristiwa penetrasi melainkan terdengar seperti proses foreplay atau pemanasan yang menggairahkan. Kendati pemenuhan hasrat seksual menjadi tujuan akhir dari hasrat itu sendiri, proses pemenuhan hasrat tersebut juga tidak kalah penting. Dengan paradigma ini, seseorang akan terhindar dari kemungkinan memanfaatkan orang lain untuk sekadar memenuhi hasratnya, melainkan terdorong untuk menikmati proses pemenuhan hasrat bersama orang tersebut. Ketika kedua belah pihak merasakan kehadiran Allah dan karya-Nya dalam proses pemenuhan hasrat tersebut, pemenuhan hasrat pun menjadi sakramen ${ }^{46}$ yang memperjumpakan Allah dengan manusia.

\section{Tentang Penulis}

Agetta Putri Awijaya dilahirkan di Klaten, 28 Agustus 1993 dan besar di Jakarta. Ia lulus dari STFT Jakarta pada tahun 2016. Ia berasal dari Gereja Kristen Indonesia dan menjalani studi teologi dengan rekomendasi dari gereja tersebut. Selama menjalani studi S1, ia menaruh minat yang besar pada Alkitab, khususnya Perjanjian Lama. Ia pernah mendapat kesempatan untuk menjalani praktik lapangan di GAYa NUSANTARA dan Free Community Church Singapura dan mulai tertarik dengan studi-studi terkait seksualitas oleh karena pengalaman-pengalaman tersebut. Karya tulis akhirnya berjudul "Mendengar Nyanyian Hasrat: Upaya Merekonstruksi Teologi mengenai Hasrat Seksual dengan Memanfaatkan Tafsir Kidung Agung 7:2-8:2 dan Pendekatan Sosio-Biologis"

${ }^{46}$ Kata "sakramen" berasal dari bahasa Latin sacramentum yang sejak abad ke-2 digunakan untuk menerjemahkan kata Yunani mysterion yang menunjuk kepada penyataan Allah dalam kehidupan manusia. Lih. Emanuel Martasudjita, LiturgiPengantar untuk Studi dan Praksis Liturgi (Jogjakarta: Kanisius, 2011), 199. 


\section{Daftar Pustaka}

Carr, Lloyd G. The Song of Solomon - An Introduction \& Commentary.

Illionis: Inter-Varsity Press, 1984.

Exum, J. Cheryl. Song of Songs: A commentary. Louisville: John Knox Press, 2005.

Ferguson, Duncan S. Biblical hermeneutics - An introduction. Louisville: John Knox Press, 1986.

Garrett, Duane. Word biblical commentary - Song of Songs, Lamentation. Texas: Word Books, 2004.

Garton, Stephen. Histories of sexuality: Antiquity to sexual revolution. London: Equinox, 2004.

Guthrie, D., et. al., Tafsiran alkitab masa kini vol. 2. Jakarta: Yayasan Komunikasi Bina Kasih, 1976.

Harrison, Roland K. Introduction to the Old Testament. Eerdmans: Grand Rapids, 1969.

Loughlin, Gerard. Alien sex - The body and desire in cinema and theology. Oxford: Blackwell Publishing, 2004.

Martasudjita, Emanuel. Liturgi - Pengantar untuk studi dan praksis liturgi. Jogjakarta: Kanisius, 2011.

Moulton, Richard G. The Literary Study of the Bible. Boston: Norwood Press, 1896.

Murphy, Roland E. The Song of Songs (Hermeneia: A Critical \& Historical Commentary on the Bible). Philadelphia: Fortress Press, 1990.

Natar, Asnath N. Realitas perempuan dalam Kidung Agung menurut teologi feminis. Diskursus, Vol. 14, No. 2 (2015): 249-269.

Pope, Marvin. H. The anchor bible - Song of Songs. New York: Doubleday\&Company, 1977.

Ryan, Christopher and Cacilda Jetha. Sex at Dawn. New York: Harper, 2010.

Scruton, Roger. Sexual desire: A philosophical investigation. New York: Continuum Publishing Company, 1986.

Stump, Eleonore, and Norman Kretzmann. The Cambridge Companion to Augustine - Classical philosophy. Oxford: Cambridge University Press, 2006.

Suchocki, Marjorie H. The fall to violence: Original sin in relational theology. New York: Continuum Publishing Company, 1994.

Tannahill, Reay. Sex in history. London: Abacus, 1980.

Tanner, J. Paul. The history of interpretation of the Song of Songs. Bibliotheca sacra vol. 154 (January-March): 23-46. Illionis: American Theological Library Association, 1997. 
Telnoni, J. A. Tafsiran Kidung Agung - Kidung pembebasan, kidung solidaritas perempuan, kidung kesetaraan perempuan dan laki-laki. Kupang: Gita Kasih, 2005. 